\title{
Seed Germination of True Prairie Forbs
}

\section{JOHN W. VOIGT}

Highlight: A study was conducted on 20 species of prairie forbs collected from Illinois tallgrass prairie to determine their levels of germination without treatment of the seed and to determine their expected higher levels of germination with various seed treatments. The present assay of forb seed germination was made to aid those engaged in prairie restoration. Seed fill was visually and physically determined. Seed viability was determined by use of triphenyl tetrazolium chloride, which turns living embryos red. Germination was done on moist filter paper inside petri plates in darkness at constant temperature. From tests on 20 species only three germinated without treatment; 12 germinated under 2 months of moist-cold treatment; and four germinated with scarification. When treated with rootone, five species germinated. Three species germinated with single application of $.005 \%$ potassium gibberellate spray. These results suggest most of the 20 species could be planted with success with the proper preparation or treatment of the seed.

The former extent of Prairie in North America or its disappearance through settlement, agriculture, and grazing, are well recorded (Weaver 1954; Transeau 1935). That this magnificent resource has all but disappeared was dramatically told in the Disney movie "The Vanishing Prairie."

Like the word ecology (until recently,, , . irie was not a household word. Hardly anyone but the professional understood that prairie was a kind of vegetational resource. As in the case of many other resources, concern was not shown until it was nearly gone. Today, for the most part, only remnants exist in most midwestern states; they are found along highways and railroad rights-of-way. These remnants are often not valid prairies but can be managed and restored to good replicas. Prairie species sometimes exist in these locations because of practices aimed at keeping down brush and tree growth. There are some managed prairies, mostly in the hands of educational institutions or owned by state governments as a part of their preservation programs. There are some smaller prairies in Illinois overlooking the Mississippi River, where they are inaccessible to cultivation (Evers 1950; Kilburn 1970).

In the past 10 years there has been a revival of interest in prairie preservation through restoration and in the use of prairie grasses and forbs in natural landscaping. In the fall of 1968 the first Symposium on Prairie Restoration was held at Knox College, Galesburg, Ill. The second symposium was held at the University of Wisconsin Arboretum in 1970 with about 300 attending. This was about a threefold increase from the first meeting. At least a third of those in attendance were lay people

Author is professor of botany, Southern Illinois University, Carbondale 62901. Manuscript received February 28, 1977. who had acquired sufficient knowledge to attend a basically scientific meeting (Anderson 1972). The Prairie Restoration Symposium has grown to an annual event, with meetings held in different geographic parts of the True Prairie Association.

Evidence of wide and increasing interest in restored prairies is shown in the number of commercial sources for prairie grass seed. Limited commercial seed has been available for reseeding grazing lands for several years. Recently, prairie grass seed has been proposed for natural landscaping purposes (Wilson 1976). Doctoral theses on prairie restoration are also noted (Christiansen 1967). Recently, native grass seed, forb seed, and pot-grown herbs are noted in a few nursery plant price lists. The pot-grown herbs are used for transplants into prairie restoration plots where grasses are established first.

Highway departments, the Corps of Engineers, and other Federal and State agencies are increasingly employing ecologists or using them as consultants in connection with prairic restoration projects. Right-of-way management has assumed new importance to all aspects of conservation. Corporate bodies such as utilities companies have shown an interest in prairie restoration on their lands. An 800 -acre prairie restoration project is now being carried out on lands owned by the National Accelerator Laboratory near Batavia, Ill. (Brukoff 1974). Establishment of prairie by corporate bodies has public relations value, educational use, and low maintenance cost.

These growing interests in prairie restoration bring a demand for forb seed which presently does not exist in quantity or quality (Sorenson and Holden 1974). The early research of Blake (1935) reveals some difficulties in the germination of the seeds of prairie species. Recent work by Sorenson and Holden (1974) revealed that $65 \%$ of 23 species of forbs investigated gave germination without treatment of moist-cold periods or scarification.

The regularly appearing forbs of a square mile of Nebraska prairie numbered 181 (Steiger 1930). Seeds of goodly number of forb species have not been studied and tested for germination performance. Prairie restoration management will be aided by further information on conditions needed for germination of other prairie forbs.

\section{Methods}

Seed for this study was collected from prairie remnant situations in Illinois mainly from two localities, one in Carroll County approximately 4 miles south of Savanna on Highway 80 and the other about 8 miles north of Carbondale, Ill., on Route 51. The following were collected from the northern Illinois station: clustered poppy mallow (Callirhoe triangulata), tickseed (Coreopsis palmata), and shaggy false gromwell (Onosmodium hispidissimum). The remaining 17 
species were from the southern site. Seeds were collected during the last week of September, 1974. Additional collections of seeds from the southern location were made about 3 weeks later the following year.

In the production of seeds, not all become filled. Germination tests were made only on those seeds which were visually judged to be filled or containing embryos. Those seeds thus selected visually were confirmed by pressing them lightly with a pair of forceps. Subsequently, the filled seeds were tested for viability by soaking overnight in $0.1 \%$ triphenyl tetrazolium chloride (TTC) (Machlis and Torrey 1956; Hartman and Kester 1968; Sorenson and Holden 1974). Seeds having a hard seed coat were cut in half with a razor blade prior to treatment with TTC.

The first germination test was a normal laboratory test. Arasan, a fungicide, was placed in a paper bag with the seeds to be tested and shaken to coat the seeds thoroughly with fungicide. The seeds were then removed to sterile petri plates containing moistened filter paper (Nichols 1934; Sorenson and Holden 1974). The petri plates were maintained in an open laboratory on tables in an air conditioned building which provided a temperature of about $75^{\circ} \mathrm{F}$. The petri plates were covered with two layers of brown wrapping paper and blotters from a plant press to provide a darkened environment. The seeds were exposed to light only for counting seeds which had germinated. Daily recordings were made of seeds germinating over a 30-day period. Each time a seed germinated, it was removed from the petri dish. Germination was considered as the emergence of the radicle from the seed coat. Germination tests on each species involved 100 seeds. A maximum of 25 seeds was placed in each petri dish. From these initial germination tests, those species failing to germinate or to germinate well were subjected to other methods of treatment to improve germination or to break dormancy. Percentages of germination are expressed as the nearest whole number.

All 20 species were subjected to moist-cold treatment. Seeds were placed on moistened filter paper in petri plates and stored in the bottom of a refrigerator for a period of 2 months. After this interval the seeds of each species were removed and tried for germination as described for normal germination. The refrigerator temperature was $40^{\circ} \mathrm{F}$ on the lower shelf where the seeds were stored.

\section{Results and Discussion}

Poor seed performance is often due to the time the seed is collected. Seed collected too early may have immature embryos. Seed collected too late may be ravaged by insects or fungus organisms, or the best seed with the best-developed embryos may have already been dispersed. Good timing in the collection of seed is based upon detailed knowledge of the life history of the plant. The collection of seed for this study was made in late September, which appears to have been generally a favorable time. Seed development in the 20 species studied ranged from 40 to $100 \%$ (Table 1).

When the seeds of 20 selected species were tested for

Table 1. Seeds developing mature embryos (\%), and seeds showing viability (\%) when tested with $0.1 \%$ triphenyl tetrazolium chloride (TTC); germination (\%) and days to germinate under 2 months of moist-cold treatment and untreated; germination (\%) after treatment with rootone and treatment with $.005 \%$ potassium gibberellate (aerosol spray), and days to germinate.

\begin{tabular}{|c|c|c|c|c|c|c|c|c|c|c|}
\hline Species & $\begin{array}{c}\text { Developing } \\
\text { embryos }\end{array}$ & $\begin{array}{l}\text { Viability } \\
\text { (TTC) }\end{array}$ & $\begin{array}{l}\text { Moist-cold } \\
\text { germination }\end{array}$ & Days & $\begin{array}{l}\text { Untreated } \\
\text { germination }\end{array}$ & Days & $\begin{array}{c}\text { Rootone } \\
\text { treated }\end{array}$ & Days & $\begin{array}{c}\text { Gibberellate } \\
\text { treated }\end{array}$ & Days \\
\hline $\begin{array}{l}\text { Biennial gaura } \\
\text { (Gaura biennis) }\end{array}$ & 60 & 98 & - & - & - & - & 77 & $14-28$ & - & - \\
\hline $\begin{array}{l}\text { Bush lespedeza } \\
\quad \text { (Lespedeza capitata) }\end{array}$ & 100 & 100 & 85 & $7-20$ & 81 & $14-20$ & 80 & $14-21$ & 87 & $14-21$ \\
\hline $\begin{array}{l}\text { Clustered poppy mallow } \\
\text { (Callirhoe triangulata) }\end{array}$ & 90 & 100 & 71 & 7 & 30 & $14-30$ & - & - & 50 & $14-21$ \\
\hline $\begin{array}{l}\text { Compass plant } \\
\quad \text { (Silphium laciniatum) }\end{array}$ & 100 & 100 & 41 & $10-14$ & - & - & - & - & - & - \\
\hline $\begin{array}{l}\text { Cup plant } \\
\text { (Silphium perfoliatum) }\end{array}$ & 100 & 100 & - & - & - & - & - & - & - & - \\
\hline $\begin{array}{l}\text { Entire-leaved rosinweed } \\
\quad \text { (Silphium integrifolium) }\end{array}$ & 54 & 100 & - & - & - & - & - & - & - & - \\
\hline $\begin{array}{l}\text { Flat-topped spurge } \\
\text { (Euphorbia corallata) } \\
\text { Feverfew }\end{array}$ & 100 & 100 & 69 & $5-20$ & - & - & - & - & - & - \\
\hline $\begin{array}{l}\text { (Parthenium integrifolium) } \\
\text { Green milkweed }\end{array}$ & 50 & 52 & - & - & - & - & - & - & - & - \\
\hline (Acerates viridiflora) & 100 & 100 & 59 & $7-20$ & - & - & - & - & - & - \\
\hline $\begin{array}{l}\text { Hairy sunflower } \\
\text { (Helianthus mollis) }\end{array}$ & 40 & 100 & 63 & $6-10$ & - & - & - & - & & \\
\hline $\begin{array}{l}\text { Long-fruited anemone } \\
\text { (Anemone cylindrica) }\end{array}$ & 100 & 74 & - & - & - & - & - & - & - & - \\
\hline $\begin{array}{l}\text { Prairie dock } \\
\quad \text { (Silphium terebinthinacium) }\end{array}$ & 70 & 100 & 73 & $8-10$ & - & - & - & - & - & - \\
\hline $\begin{array}{l}\text { Rattlebox } \\
\qquad \text { (Crotalaria saggitalis) }\end{array}$ & 90 & 100 & - & - & - & - & 20 & $3-20$ & - & - \\
\hline $\begin{array}{l}\text { Rattlesnake master } \\
\text { (Eryngium vuccifolium) }\end{array}$ & 63 & 90 & - & - & - & - & - & - & - & - \\
\hline $\begin{array}{l}\text { Shaggy false gromwell } \\
\text { (Onosmodium hispidissimum) }\end{array}$ & 100 & 100 & - & - & - & - & - & - & - & - \\
\hline $\begin{array}{l}\text { Squarrose blazing star } \\
\text { (Liatris squarrosa) }\end{array}$ & 80 & 60 & 42 & $14-21$ & - & - & - & - & - & - \\
\hline $\begin{array}{l}\text { Tall baptisia } \\
\text { (Baptisia leucantha) }\end{array}$ & 100 & 100 & 2 & 7 & - & - & - & - & - & - \\
\hline $\begin{array}{l}\text { Tall blazing star } \\
\quad \text { (Liatris pycnostachya) }\end{array}$ & 70 & 50 & 40 & $14-21$ & - & - & - & - & - & - \\
\hline $\begin{array}{l}\text { Tickseed } \\
\quad \text { (Coreopsis palmata) }\end{array}$ & 50 & 96 & 98 & $6-12$ & 40 & $4-30$ & 40 & $14-21$ & - & - \\
\hline $\begin{array}{l}\text { Virginia lespedeza } \\
\quad \text { (Lespedeza virginica) }\end{array}$ & 73 & 87 & 39 & $14-20$ & - & - & 30 & $14-21$ & 70 & $14-21$ \\
\hline
\end{tabular}


germination without any kind of treatment after gathering, only three showed germination (Table 1). Twelve species showed germination after receiving a moist-cold treatment for 2 months. The percentages of germination of these twelve species ranged from 2 to $98 \%$ (Table 1).

Moist-cold treatment improved germination of the three species which had germinated without any kind of treatment. No species were found in which the moist-cold treatment reduced the germination percentage over that achieved without treatment. The moist-cold treatment results in after-ripening and produces embryonic growth or metabolic change within the embryo (Hartman and Kester 1968; Mayer and PoljakoffMayber 1968).

Some species remain dormant because of a seed coat which is a many-layered membrane of impervious nature or whose outer layer is covered with waxy substances impervious to water or gasses. Many Composites such as rosinweeds, tickseed, some sunflowers, and the blazing stars have such waxy coverings on the seed coat. Such species, after being given the moist-cold treatment also had their seed scarified by nicking them or slicing a thin section from the edge of the seed. This combined treatment gave germination of seven species, usually within 2 weeks. Seven other species showed no germination response to this treatment.

There are other species which have hard and mechanically resistant seed coats. There were four species which responded to scarification of the seed coat as a single treatment. The legume family is notable for this feature, and two of the four species belonged to this family (Table 2 ).

Table 2. Seed germination (\%) of four prairie forbs after scarification treatment, and days to germinate.

\begin{tabular}{lcc}
\hline \hline Species & $\begin{array}{c}\text { Percent } \\
\text { germination }\end{array}$ & Days \\
\hline Clustered poppy mallow (Callirhoe triangulata) & 90 & $14-17$ \\
Battlebox (Crotalaria saggitalis) & 100 & $3-5$ \\
Shaggy false gromwell (Onosmodium hispidissimum) & 80 & $8-20$ \\
Tall baptisia (Baptisia leucantha) & 100 & 7 \\
\hline
\end{tabular}

Scarification was done with an emory board such as used in filing fingernails. Small seeds were held with forceps and ten strokes of the fine side of the emory board usually broke the seed coat. Because of the tedious nature of this technique the number of seeds per petri plate, for this part of the experiment, was reduced to ten. With four replications the total number of seeds thus tested was 40 for each species. The germination percentage ranged from 80 to $100 \%$ and generally occurred promptly (Table 2).
Dormancy may sometimes be broken with chemical growthproducing substances or hormones. Seeds of all 20 species were treated with both the commercial rootone powder and the .005\% potassium gibberellate from an aerosol can. Five species responded to rootone, but only one of these showed improved germination over that of the other treatments. A species whose secds showed no germination under other treatments was the biennial gaura. It showed a germination of $77 \%$ when treated with rootone. Only three species had seeds which germinated when treated with one application of the gibberellate spray. The bush lespedeza and Virginia lespedeza gave improved germination percentages with 87 and $70 \%$ respectively (Table 1).

\section{Conclusions}

The germination of prairie forb seed is high enough with the proper treatment for each kind of seed that good success in planting can be expected. This should be true either in field seeding or growing in the greenhouse in pots or flats. Because of certain advantages such as control of competition the latter method is often favored. The germination response after proper seed treatment ranges from 6 days to 30 days. Germination for most species is around 2 weeks.

\section{Literature Cited}

Anderson, R. 1972. The prairies. Outdoor Illinois. p. 19-26.

Blake, A. K. 1935. Viability and germination of seeds and early life history of prairie plants. Ecol. Monogr. 5:405-460.

Brukoff, J. M. 1974. The national accelerator aids a native prairie. Outdoor Illinois, October.

Christiansen, P. A. 1967. Establishment of prairie species in lowa by seeding and transplanting. PhD Thesis, Iowa State Univ.

Evers, R. A. 1952. Hill prairies of Illinois. PhD Thesis, Univ. of Illinois. Hartmman, H. T., and D. E. Kester. 1968. Plant propagation principles and practices. Prentice-Hall, Inc., Englewood Cliffs, New Jersey. p. 102, 127, 156.

Kilburn, Paul D. 1970. Hill prairie restoration. Proceedings of a symposium of prairie and prairie restoration. Knox College, Galesburg, Illinois. p. 50-51.

Machlis, L., and J. G. Torrey. 1956. Plants in action-a laboratory manual of plant physiology. W. H. Freeman and Co., San Francisco, California. p. 28, 36, 44-46.

Mayer, A. M., and A. Poljakoff-Mayber. 1963. The germination of seeds. The Macmillan Company, New York. p. 61-98.

Nichols, G. E. 1934. The influence of exposure to winter temperatures upon seed germination in various native American plants. Ecology 15:364-373.

Sorenson, J. T., and D. J. Holden. 1974. Germination of native prairie forb seeds. J. Range Manage. 27:123-126.

Steiger, T. L. 1930. Structure of prairie vegetation. Ecology 11:170-217.

Transeau, E. N. 1935. The prairie peninsula. Ecology 16:423-437.

Weaver, J. E. 1954. North American prairie. Johnsen Publ. Co., Lincoln, Nebraska. 348 p.

Wilson, J. M. 1976. Plant prairie grass. Horticulture 54(3):24-30. 